\title{
Retraction Note to: The role of the Islamic Azad University in science production of Iran: from the past to the future
}

\author{
Ali Nazari ${ }^{1}$
}

Published online: 24 May 2021

(C) Springer-Verlag London Ltd., part of Springer Nature 2021

Retraction Note to: Neural Comput \& Applic (2013) 23:311-322 https://doi.org/10.1007/s00521-012-0898-1

The Editor-in-Chief has retracted this article because it significantly overlaps with previously published articles $[1,2]$, and an article that was under consideration at the same time [3]. Additionally, the article shows evidence of peer review manipulation. The author has not responded to any correspondence regarding this retraction.

\section{References}

1. Nazari A (2013) Retracted article: Application of artificial neural networks for analytical modeling of Charpy impact energy of functionally graded steels. Neural ComputApplic 22:731-745. https://doi.org/10.1007/s00521-011-0761-9

2. Bohlooli H, Nazari A, Kaykha MM (2013) Retracted: Microhardness profile prediction of functionally graded steels by artificial neural networks. Int J Damage Mech 22(1):17-36. https://doi.org/ $10.1177 / 1056789511432653$

3. Nazari A (2013) Retracted article: Artificial neural networks for prediction compressive strength of geopolymers with seeded waste ashes. Neural ComputApplic 23:391-402. https://doi.org/10.1007/ s00521-012-0931-4

Publisher's Note Springer Nature remains neutral with regard to jurisdictional claims in published maps and institutional affiliations.
The original article can be found online at https:// doi.org/10.1007/s00521-012-0898-1.

\section{Ali Nazari}

alinazari84@aut.ac.ir

1 Department of Materials Science, Saveh Branch, Islamic Azad University, Saveh, Iran 